POETRY IN SPEECH 
A volume in the series

MYTH AND POETICS

edited by GREGORY NAGY

A full list of titles in the series appears at the end of the book. 


\section{POETRY IN SPEECH Orality and Homeric Discourse}

Egbert J. BAKKer

CORNELL UNIVERSITY PRESS

ITHACA AND LONDON 
Open access edition funded by the National Endowment for the Humanities/ Andrew W. Mellon Foundation Humanities Open Book Program.

\section{Copyright (C) 1997 by Cornell University}

All rights reserved. Except for brief quotations in a review, this book, or parts thereof, must not be reproduced in any form without permission in writing from the publisher. For information, address Cornell University Press, Sage House, 512 East State Street, Ithaca, New York 14850, or visit our website at cornellpress.cornell.edu.

First published 1997 by Cornell University Press

Library of Congress Cataloging-in-Publication Data

Bakker, Egbert J.

Poetry in speech : orality and Homeric discourse / Egbert J. Bakker.

p. cm. - (Myth and poetics)

Includes bibliographical references and indexes.

ISBN-13: 978-0-8014-3295-8 (cloth) — ISBN-13: 978-1-5017-2276-9 (pbk.)

1. Homer-Criticism and interpretation. 2. Epic poetry, Greek-History and criticism. 3. Discourse analysis, Literary. 4. Oral formulaic analysis. 5. Oral tradition-Greece. 6. Speech in literature. 7. Poetics. I. Title.

PA4037.B33 1996

$883^{\prime} .01-\mathrm{dc} 20 \quad 96-31979$

The text of this book is licensed under a Creative Commons Attribution-NonCommercial-NoDerivatives 4.0 International License: https://creativecommons.org/licenses/by-nc-nd/4.0/ 